\title{
A Versatile and Practical Synthesis toward the Development of Novel HIV-1 Integrase Inhibitors
}

\author{
Marta Rinaldi, ${ }^{[a]}$ Cristina Tintori, ${ }^{[a]}$ Luigi Franchi, ${ }^{[a]}$ Giulia Vignaroli, ${ }^{[a]}$ Anna Innitzer, ${ }^{[a]}$ \\ Silvio Massa, ${ }^{[a]}$ José A. Esté, ${ }^{[\mathrm{d}]}$ Encarna Gonzalo, ${ }^{[\mathrm{d}]}$ Frauke Christ, $^{[\mathrm{b}]}$ Zeger Debyser, $^{[\mathrm{b}]}$ and \\ Maurizio Botta*[a, c]
}

\begin{abstract}
As a continuation of our previous work, which resulted in the identification of a new hit compound as an HIV-1 integrase inhibitor, three novel series of salicylic acid derivatives were synthesized using three versatile and practical synthetic strategies and were assayed for their capacity to inhibit the catalytic activity of HIV-1 integrase. Biological evaluations revealed that some of the synthesized compounds possess good inhibitory
\end{abstract}

potency in enzymatic assays and are able to inhibit viral replication in MT-4 cells at low micromolar concentrations. Finally, docking studies were conducted to analyze the binding mode of the synthesized compounds within the DNA binding site of integrase in order to refine their structure-activity relationships.

\section{Introduction}

Acquired immunodeficiency syndrome (AIDS), caused by the human immunodeficiency virus (HIV), has become a major epidemic, infecting more than 39 million people worldwide. State-of-the-art highly active antiretroviral therapy (HAART) against this lethal disease is based on cocktails of different drug classes that target various steps of the HIV replication cycle. Before late 2007, four different drug classes had been approved by the US Food and Drug Administration (FDA) for the treatment of AIDS: 1) nucleoside reverse transcriptase inhibitors, 2) non-nucleoside reverse transcriptase inhibitors, 3) protease inhibitors, and 4) fusion inhibitors. ${ }^{[1,2]}$ These drugs have proven successful for the treatment of HIV-1, but considering their adverse side effects and the emergence of resistant mutant strains, new therapies against the HIV virus are urgently required. ${ }^{[3,4]}$ In October 2007, the FDA approved raltegravir (MK-0518), the first example of a drug active against HIV-1 integrase (IN), validating IN as a new target in the field of anti-HIV drug research. ${ }^{[5-7]}$

IN is an essential enzyme for the integration of viral DNA into the host cell genome. The process occurs in two spatially and temporally different steps known as $3^{\prime}$ processing and strand transfer. The $3^{\prime}$ processing event occurs in the cytoplasm, where IN binds the viral DNA and then removes a dinucleotide from each strand at the $3^{\prime}$ end adjacent to a conserved CA sequence. The formed complex is then transported into the nucleus, where the strand transfer reaction takes place, and the $3^{\prime}$ ends of the viral DNA are covalently linked to the $5^{\prime}$ ends of the host cell DNA. ${ }^{[8-10]}$ The essential multifunctional role of IN in the viral replication cycle and the absence of a counterpart in host cells make this enzyme an interesting target for the development of new anti-HIV drugs. During the past few years, many studies have been focused on the discovery of novel potential integrase inhibitors. ${ }^{[11-13]}$ In this context, we recently disclosed our own work in the field, presenting a virtual screening protocol ${ }^{[14,15]}$ that allowed us to identify a new hit (compound 17) ${ }^{[16]}$ which proved to be active against both the integration activity of IN and HIV-1 replication at the micromolar level. Furthermore, the synthesis and biological evaluation of a small family of structurally related compounds were performed. ${ }^{[17]}$<smiles>O=C1NC(=S)NC(=O)C1=Cc1ccc(-c2ccc(C(=O)O)c(O)c2)o1</smiles>

We found that some of the synthesized compounds exhibit inhibitory potency against IN and antiviral activity in cellular assays at micromolar concentrations. The biological results in-

[a] Dr. M. Rinaldi, Dr. C. Tintori, Dr. L. Franchi, Dr. G. Vignaroli, Dr. A. Innitzer, Prof. S. Massa, Prof. M. Botta

Dipartimento Farmaco Chimico Tecnologico

Università degli Studi di Siena, Via A. De Gasperi 2, 53100 Siena (Italy)

Fax: (+ 39) 0577234333

E-mail:botta@unisi.it

[b] Dr. F. Christ, Prof. Z. Debyser

Molecular Medicine, Katholieke Universiteit Leuven Kapucijnenvoer 33, 3000 Leuven, Flanders (Belgium)

[c] Prof. M. Botta

Biotechnology, College of Science and Technology

Temple University, Biolife Science Building

Suite 333, 1900 N. $12^{\text {th }}$ Street, Philadelphia, PA 19122 (USA)

[d] Prof. J. A. Esté, Dr. E. Gonzalo

Laboratori de Retrovirologia irsiCaixa

Hospital Universitari Germans Trias i Pujol

Universitat Autònoma de Barcelona

Ctra. Del Canyet s/n, 08916 Badalona (Spain) 
dicate that: 1) the acidic moiety is fundamental for the activity; 2) the potency of these compounds could be improved by the introduction of hydroxy groups on the phenyl moiety; 3) the introduction of substituents at position 3 of the furan ring leads to compounds with inferior activity; and 4) the thiobarbituric acid group can be substituted with other heterocyclic moieties, such as rhodanine or thiohydantoin, without loss of activity.

Docking studies with hit compound 17 (Figure 1) suggest that the salicylic ring is located in the region usually occupied by the phosphate groups of viral DNA, where it establishes

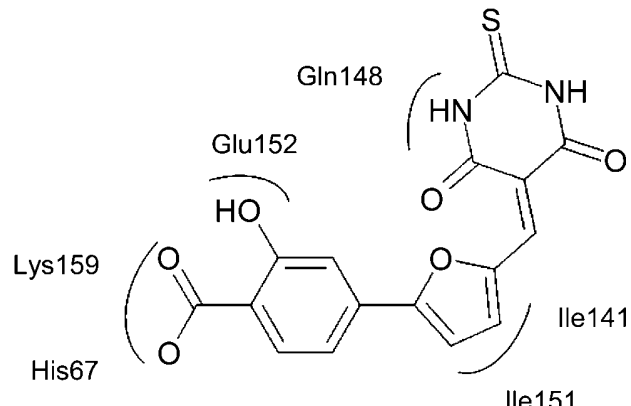

Figure 1. Schematic representation of the binding mode of compound 17.

strong electrostatic interactions with Lys159. Interestingly, Lys159 is involved in the specific recognition of viral DNA by integrase, and alteration of this contact has been proposed as the mechanism of action of $3^{\prime}$-processing inhibitors. ${ }^{[13]}$ On the other hand, the thiobarbituric moiety is directed toward a very flexible loop containing amino acid residues 140-149, and its $\mathrm{NH}$ group interacts with the backbone carbonyl group of Gln148. The 140-149 loop has been proposed to be involved in a conformational modification of the enzyme after binding with DNA, and consequently, stabilization of the viral DNA-IN complex. ${ }^{[13,18]}$ Through mutagenesis and photo-crosslinking studies, several amino acids that are involved in the DNA binding of IN, in particular Tyr143, have been identified, although these do not belong directly to the catalytic site of the enzyme. ${ }^{[19,20]}$

In this work, pursuing our goal to identify novel HIV-1 IN inhibitors capable of blocking the IN-viral DNA interaction, and taking into account structure-activity relationship studies performed on the previous set of compounds, ${ }^{[17]}$ we synthesized three new series of second-generation salicylic acid derivatives ( $A, B$, and $C$ in Figure 2). These compounds were designed to investigate the influence of synthetic derivatizations at position
5 of the furan ring, keeping the 2-salicylic furan moiety fixed. The new compounds $A, B$, and $C$ allowed us to explore whether molecules in these series engage in stronger interactions with the 140-149 loop than the previously reported hit compound 17. Concerning series A derivatives, we replaced the heterocycle of compound $\mathbf{1 7}$ with a benzyl moiety linked directly to the furan ring (general structure A, Figure 2), keeping the salicylic biaryl portion of the molecule fixed, which was suggested to be crucial for activity. ${ }^{[15]}$ This modification was attempted to better investigate two aspects: 1 ) the importance of the hydrogen bond interaction established by the hit $\mathbf{1 7}$ with the backbone carbonyl group of Gln148 (determining whether it is essential for the inhibition of IN activity); and 2) the influence of more extensive hydrophobic contacts with the 140-149 loop on receptor binding . Furthermore, we designed two series of 2-salicylic furan derivatives containing a substituted rhodanine moiety at position 5 of the furan ring (general structures B and C, Figure 2). The aim of this modification was to obtain elongated molecules capable of establishing more extensive interactions within the binding site, especially with Tyr143, which was shown to be an important residue for IN binding with DNA. Various substituents were introduced at two different positions of the rhodanine ring to explore the space around the heterocycle. Biological results showed that among the benzyl derivatives, only one compound possesses weak activity against IN. In contrast, the approach to the substituted rhodanines was more successful; in fact, most of the compounds with general structure $C$ (Figure 2) showed good activity results in the IN inhibition assay. Moreover, docking studies with the new synthesized compounds are in agreement with biological data and help to refine the structure-activity relationship analysis.

\section{Results and Discussion}

\section{Chemistry}

The final compounds with general structure A were obtained by starting from the commercially available methyl-4-iodosalycilate 1, which was used in a Suzuki coupling with the 2-furanboronic acid 2 (Scheme 1). The coupled product 3 was then hydrolyzed with an aqueous solution of sodium hydroxide to afford the free acid analogue 4, which was protected with TIPSCI. The protected compound $\mathbf{5}$ was treated with various Grignard reagents: 4-fluorophenylmagnesium bromide $6 \mathrm{a}, 3$ fluorophenylmagnesium bromide $\mathbf{6 b}$, and 3-phenylphenylmagnesium bromide $6 c$. In the case of the 4-fluorobenzyl derivative $7 \mathbf{a}$, the protecting groups were removed directly with TBAF to yield the final compound $\mathbf{8} \mathbf{a}$; in the other cases, compounds 7 a-c were simultaneously reduced and deprotected with $\mathrm{TMSCl}$ and Nal to obtain the final compounds $\mathbf{9} \mathbf{a}-\mathbf{c}$. In most cases, synthetic steps proceeded with acceptable yield. However, an optimized proce-

Figure 2. General structures of the three novel series of compounds. 


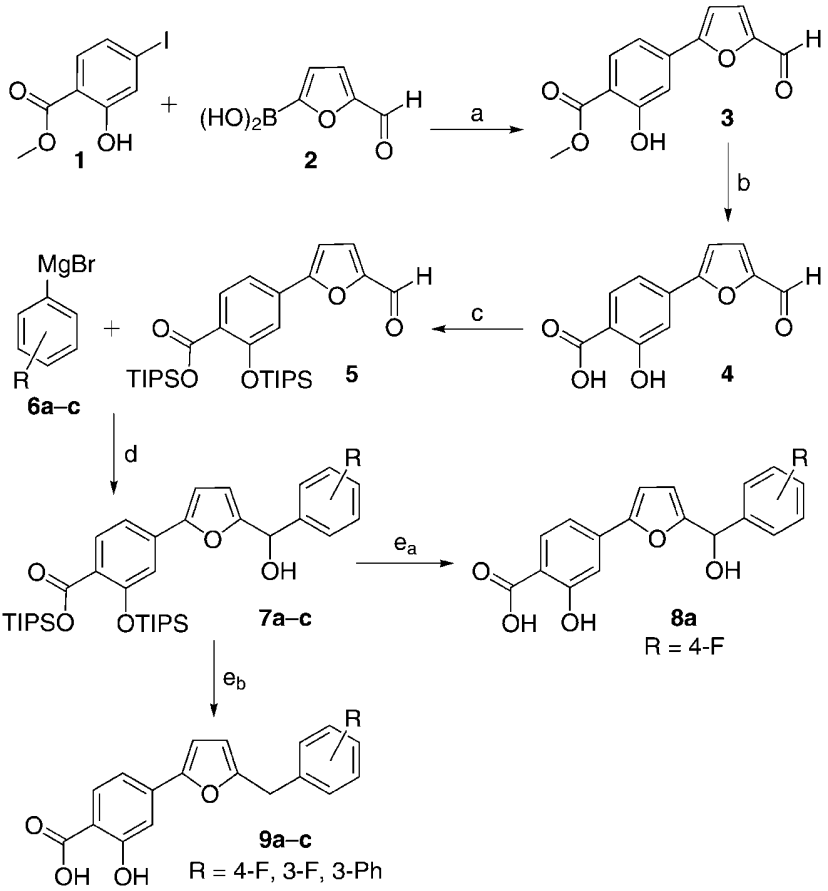

Scheme 1. Synthesis of benzyl derivatives $\mathbf{8}$ a and $\mathbf{9 a - c}$ : a) $\mathrm{Pd}\left(\mathrm{PPh}_{3}\right)_{2} \mathrm{Cl}_{2}$, $\mathrm{Na}_{2} \mathrm{CO}_{3}, \mathrm{DMF} / \mathrm{EtOH}, \mathrm{RT}, 1.5 \mathrm{~h}$; b) $1 \mathrm{~N} \mathrm{NaOH}, \mathrm{CH}_{3} \mathrm{OH}$, reflux, overnight; c) TIPSCl, imidazole, dry DMF, $0 \rightarrow 60^{\circ} \mathrm{C}, 16 \mathrm{~h}$; d) Grignard reagent, dry THF, $-78^{\circ} \mathrm{C}, 1 \mathrm{~h} ; \mathrm{e}_{\mathrm{a}}$ ) TBAF, dry THF, $\left.0^{\circ} \mathrm{C} \rightarrow \mathrm{RT}, 30 \mathrm{~min} ; \mathrm{e}_{\mathrm{b}}\right) \mathrm{TMSCl}$, Nal, dry $\mathrm{CH}_{3} \mathrm{CN}$, $30 \mathrm{~min}$. by changing only the amine employed. We used morpholine, thiomorpholine, and $\mathrm{N}$-methylpiperazine as secondary amines, while benzylamine was used as the primary amine (Table 1). After dissolving all reagents in ethanol, heating at $150^{\circ} \mathrm{C}$ for $20 \mathrm{~min}$ by microwave irradiation is required to effect completion. After acidic workup, the desired products are collected by filtration from ethanol.

The other series of substituted rhodanine derivatives with general structure $C$ was obtained by exploiting a very practical and rapid procedure that was recently developed by our research group (Scheme 3). ${ }^{[26]}$ This methodology consists of a sequential, one-pot, two-step process under microwave-assisted irradiation and allows the formation of desired final compounds in just a few minutes with high purity after a simple precipitation under acidic conditions.

Following the optimized protocol, bis(carboxymethyl)trithiocarbonate and the suitable amine were dissolved in DME in the presence of triethylamine, and the resulting mixture was heated at $90^{\circ} \mathrm{C}$ under microwave irradiation for $10 \mathrm{~min}$. After this time, the 5 -aryl-2-furaldehyde 4 was added, and the reaction mixture was heated again at $110^{\circ} \mathrm{C}$ under microwave irradiation for $5 \mathrm{~min}$. The desired compounds were obtained by filtration from methanol under acidic conditions.

This methodology allowed us to obtain, in a very short time, a collection of final compounds for testing against HIV-1 IN activity. Considering the versatility and efficiency of the protocol, dure for the direct and regioselective arylation of 2-acylfurans was recently reported. ${ }^{[21]}$ All compounds belonging to this series are listed in Table 1.

To generate compounds with general structure $B$, several procedures have been reported; ${ }^{[22-25]}$ we adapted a recently published synthetic strategy that describes a one-pot, multicomponent, microwave-assisted reaction that allows the desired final compounds to be obtained directly (Scheme 2). ${ }^{[22]}$ The methodology involves 5-aryl-2-furaldehyde 4 (synthesized as reported above), rhodanine, and several secondary or primary amines (11 a-d) that catalyze a Knoevenagel condensation between the aldehyde and rhodanine, and then act as nucleophiles in the displacement of the thiocarbonyl sulfur. This microwave-assisted procedure allows one to obtain, in very short reaction times and easy workup, several final compounds we employed both aromatic and aliphatic primary amines to better investigate how the nature of the substituents can affect the interactions with the IN binding site. The final compounds $16 \mathbf{a}-\mathbf{n}$ are listed in Table 1 .

Compounds $12 \mathbf{a}-\mathbf{d}$ and $16 \mathbf{a}-\mathbf{n}$ are present as potential $E$ and $Z$ isomers: in all cases, in the ${ }^{1} \mathrm{H}$ and ${ }^{13} \mathrm{C}$ NMR spectra of compounds $12 \mathrm{a}-\mathbf{d}$ and $16 \mathrm{a}-\mathbf{n}$, only one isomer was observed, and the $Z$ configuration was assigned by the ${ }^{3} \mathrm{~J}_{\mathrm{C}_{4} \mathrm{H} 6}$ coupling constant measurement. In fact, the experimental $J$ values of these derivatives are in agreement with those previously reported for analogous 4-thiazolidinones. ${ }^{[22-25,27-30]}$

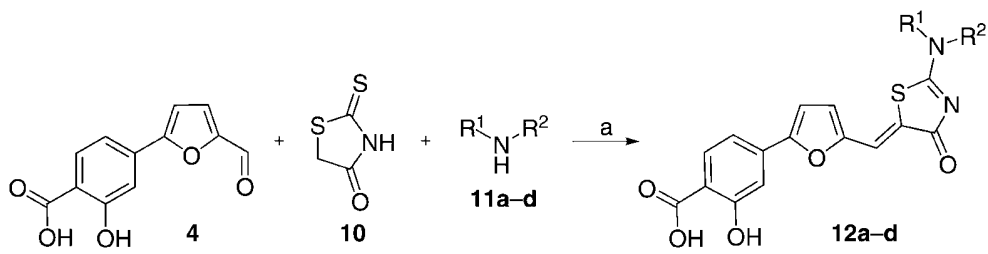

Scheme 2. Synthesis of substituted rhodanine derivatives $12 \mathrm{a}-\mathbf{d}$ : a) EtOH, $150^{\circ} \mathrm{C}, \mathrm{MW}$, $20 \mathrm{~min}$.

\section{Biological activity and docking studies}

All the synthesized compounds were tested with an ELISA-based IN activity assay, and the biological results are listed in Table $1{ }^{[31,32]}$ Concerning benzyl derivatives, the results show that only compound $\mathbf{8 a}$ possesses weak activity against the HIV-1 virus. For these derivatives, docking studies suggest a binding 
Table 1. Anti-IN activity of compounds $8 \mathrm{a}, 9 \mathrm{a}-\mathrm{c}, 12 \mathrm{a}-\mathrm{d}$, and $16 \mathrm{a}-\mathbf{n}$
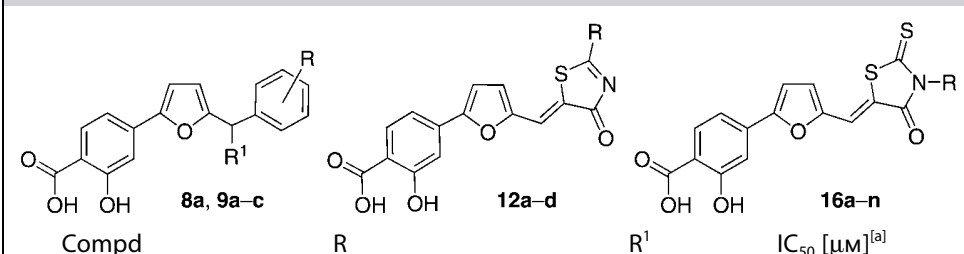

8

9 a

$9 \mathrm{~b}$

$9 c$

$12 \mathrm{a}$

$\mathrm{OH} \mathrm{OH} \quad 12 \mathrm{a}-\mathrm{d}$ $\mathrm{R}^{1} \mathrm{OH} \mathrm{OH}$

$\mathrm{IC}_{50}[\mu \mathrm{M}]^{[\mathrm{a}]}$

$4-\mathrm{F}$
$4-\mathrm{F}$
$3-\mathrm{F}$
$3-\mathrm{Ph}$
$\mathrm{O}$

$12 \mathrm{~b}$<smiles>C1CSCCN1</smiles>

$93.0 \pm 5.0$

$12 \mathrm{c}$<smiles>C</smiles>

$\mathrm{CH}_{3}$

$12 d$

$16 a$

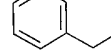

$130.0 \pm 39.0$

F

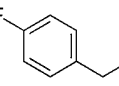

$6.9 \pm 1.2$

$16 \mathrm{~b}$

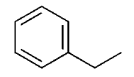

$3.7 \pm 1.1$

ó

$16 c$

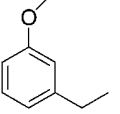

$32.8 \pm 11.5$

$202.3 \pm 67.0$

$16 d$

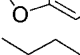

$114.9 \pm 3.7$

$\triangle$

$86.1 \pm 5.4$

$16 \mathrm{f}$

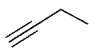

$140.3 \pm 8.7$

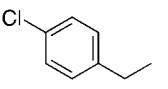

$17.3 \pm 3.8$

$16 \mathrm{~h}$

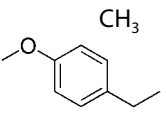

$>125$

16I

$20.4 \pm 2.3$

$24.1 \pm 5.8$
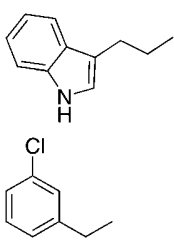

$33.8 \pm 10.0$

$8.9 \pm 0.01$

MK-0518 activity. Interestingly, the difference between the fairly active compound $\mathbf{8} \mathbf{a}$ and the reduced analogue $9 \mathrm{a}$ is represented by the hydroxy group formed after allowing the Grignard reagent to react with the aldehyde. Therefore, such a hydroxy group is responsible for the moderate activity exhibited by compound $\mathbf{8} \mathbf{a}$. In agreement with this observation, the docking calculation for compound $\mathbf{8} \mathbf{a}$ highlighted that such $a$ hydroxy group could positively interact with Asp116 through a hydrogen bond contact when the chiral center is the $S$ configuration (Figure 4).

Regarding the biological results of the substituted rhodanine derivatives, the three compounds $12 \mathrm{a}$, $12 \mathrm{~b}$, and $12 \mathrm{~d}$ showed moderate activity in the IN inhibition assays, whereas compounds $16 \mathbf{a}-\mathbf{n}$ gave more satisfactory results. In the series of substituted rhodanine derivatives $16 \mathbf{a}-\mathbf{n}$, a substituent-dependent effect was observed: the best results were obtained when aromatic moieties were introduced on the rhodanine ring, while the substitution with aliphatic groups at the same position of this ring decreased the inhibitory potency against HIV-1 IN.

Considering these results, we aimed to determine a comprehensive structure-activity relationship. It was observed that the first attempt at molecular complication, which led to the study of compounds 12 a-d, was unsuccessful. Docking studies with these compounds did not converge to a highly populated cluster, suggesting that such compounds may be unable to find a stable pose in the binding site. A different behavior was observed in the docking studies with derivatives 16a-n. All these compounds were found to bind the DNA binding site of IN with an orientation similar to that of the hit compound 17, discussed above. Specifically, the salicylic ring is engaged in hydrogen bonding with polar amino acid residues: hydrogen bond contacts between the acidic group of the inhibitor and the side chain of Lys159 as well as with the backbone $\mathrm{NH}$ group of His67 contribute significantly to the stabilization of the complex. In addition, the hydroxy group is involved in a hydrogen bond with Glu152. On the other hand, the rhodanine moiety is directed toward the 140-149 loop, and positive van der Waals contacts involving the side chains of Ile151 and lle141 were found. Moreover, another hydrophobic interaction was observed between the rhodanine substituent and Tyr143 for compounds substituted with aromatic groups such as $16 \mathrm{a}-\mathrm{d}, 16 \mathrm{~h}$, and $16 \mathrm{I}-\mathrm{n}$. This additional hydrophobic contact could explain the improved activity observed if aromatic moieties are in- mode similar to that of the hit compound 17. As an example, Figure 3 shows the predicted binding mode for compound 9 a.

Despite the fact that the benzyl moiety establishes positive van der Waals contacts within the binding site, the loss of the hydrogen bond interaction established between the heterocycle of compound 17 and Gln148 appears to be detrimental for troduced on the rhodanine ring (16a-c, 16h, and $16 \mathrm{I}-\mathrm{n})$ rather than aliphatic groups (16 e-g, 16i). For compounds $16 \mathrm{a}-\mathrm{c}, 16 \mathrm{~h}$, and $16 \mathrm{I}-\mathrm{n}$, the loss of a hydrogen bond with Gln148 seems to be compensated by the van der Waals interaction with Tyr143. For example, Figure 5 shows the predicted binding mode of compound $16 \mathrm{a}$. 


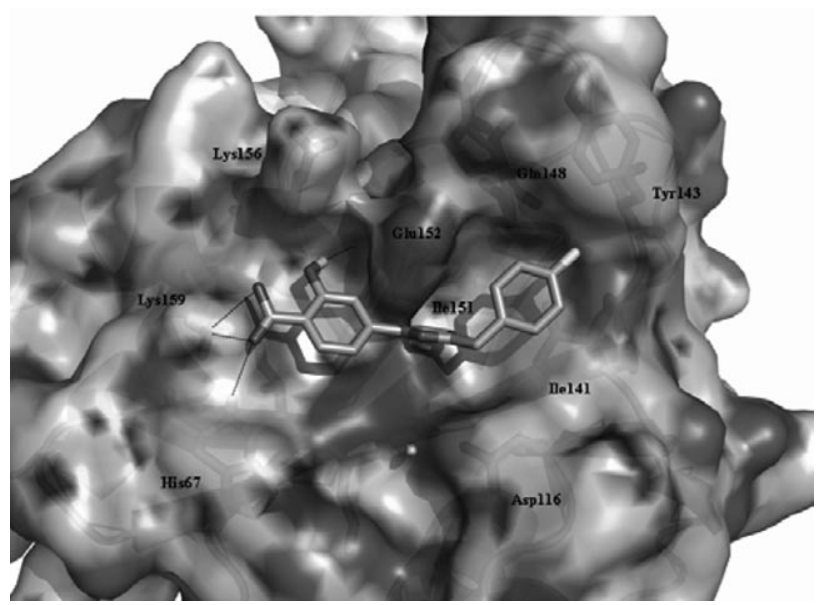

Figure 3. Graphical representation of the binding mode of compound $\mathbf{9} \mathbf{a}$. For clarity, only a few residues are labeled; nonpolar hydrogen atoms are omitted, and hydrogen bond interactions are represented by black dashed lines.

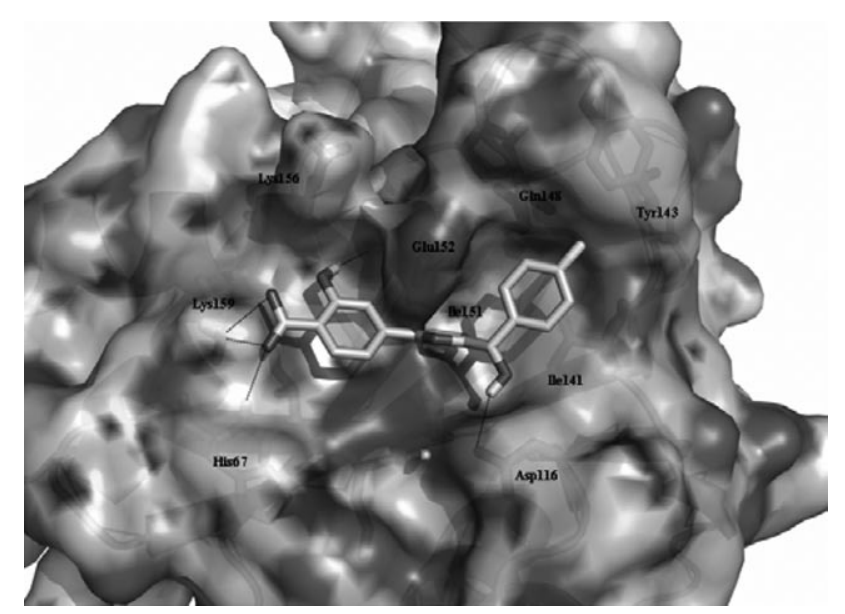

Figure 4. Graphical representation of the binding mode of compound $\mathbf{8} \mathbf{a}$. For clarity, only a few residues are labeled; nonpolar hydrogen atoms are omitted, and hydrogen bond interactions are represented by black dashed lines.

Some of the more interesting compounds belonging to this series were also tested in 3 '-processing and ST assays, but no great difference in terms of activity was observed between the two steps.

The most active compounds in terms of overall integration activity, $16 \mathrm{a}$ and $16 \mathrm{~b}$ as well as the inactive compounds $12 \mathrm{a}$ and $16 \mathrm{~d}$, were selected to evaluate their ability to inhibit the HIV-induced cytopathic effect in a human lymphocyte MT-4 cell culture infected with HIV-1 NL4-3 (wt) using the MT-4/MTT assay. ${ }^{[3,34]}$ Remarkably, compounds $16 \mathrm{a}$ and $16 \mathrm{~b}$ showed low micromolar activity $\left(\mathrm{EC}_{50}=1.7\right.$ and $8.2 \mu \mathrm{M}$, respectively), whereas compounds $12 \mathrm{a}$ and $16 \mathrm{~d}$ were inactive at subtoxic concentrations (Table 2). Further modifications of compounds $16 \mathbf{a}-\mathbf{b}$ aiming at improving these results are in progress.

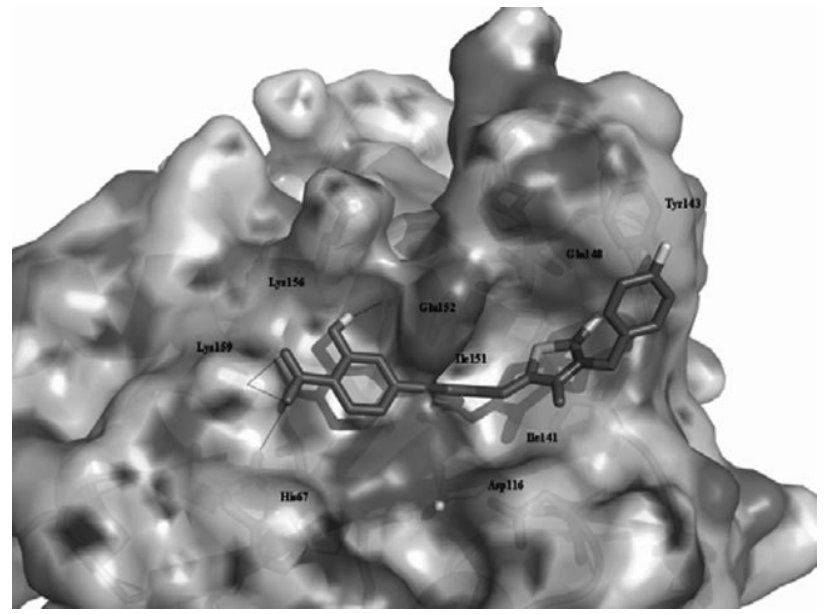

Figure 5. Graphical representation of the binding mode of compound $16 \mathrm{a}$. For clarity, only a few residues are labeled; nonpolar hydrogen atoms are omitted, and hydrogen bond interactions are represented by black dashed lines.

\begin{tabular}{|c|c|c|c|}
\hline Compd & $\mathrm{EC}_{50}[\mu \mathrm{M}]^{[\mathrm{a}]}$ & $\mathrm{CC}_{50}[\mu \mathrm{M}]^{[\mathrm{b}]}$ & $\mathrm{SI}\left[\mathrm{CC}_{50} / \mathrm{EC}_{50}\right]$ \\
\hline $16 a$ & 1.7 & 31 & 18 \\
\hline $16 \mathrm{~b}$ & 8.2 & 27 & 3 \\
\hline $16 d$ & $>15$ & 15 & - \\
\hline $12 a$ & $>50$ & $>50$ & - \\
\hline 17 & 15 & $>140$ & $>9$ \\
\hline MK-0518 & 0.0008 & $>2$ & $>2600$ \\
\hline
\end{tabular}

[a] Effective concentration required to decrease HIV-1-induced cytopathic effect by $50 \%$ in MT-4 cells. [b] Cytotoxic concentration required to decrease MT-4 cell viability by $50 \%$. Values represent the mean of two experiments.

\section{Conclusions}

We designed and synthesized three novel series of salicylic acid derivatives $8 \mathbf{a}, \mathbf{9 a}-\mathbf{c}, 12 \mathrm{a}-\mathbf{d}$, and $16 \mathbf{a}-\mathbf{n}$ to investigate their activity against HIV-1 IN. In particular, compounds 12 a-d and $16 \mathbf{a}-\mathbf{n}$ were obtained by using microwave-assisted procedures that were developed and optimized in our research group, which allowed us to obtain several final compounds of high purity in a short time.

Biological evaluation revealed that some of the synthesized compounds possess good inhibitory potency in enzymatic assays. Docking studies of the new molecules were successfully used to rationalize their structure-activity relationship. The results of these simulations show that the hydrogen bond between our previously reported hit compounds and GIn148 is a crucial interaction for determining the affinity toward IN. In fact, the ligands that cannot form the same hydrogen bond contact are characterized by loss of activity. The IN inhibitory activity could be restored for compounds that are able to establish extensive van der Waals interactions with Tyr143. Overall, these results emphasized Gln148 and Tyr143 as two important residues to be targeted for the design of new IN inhibi- 
tors. Compounds $16 \mathrm{a}$ and $16 \mathrm{~b}$ were also able to inhibit HIV replication in MT-4 cells at low micromolar concentrations with an appreciable selectivity index (SI), indicating that aromaticsubstituted rhodanines are also good scaffolds for further development of IN inhibitors. Further modifications of these new hit compounds, with the aim of improving activity, are currently ongoing in our laboratories.

\section{Experimental Section}

\section{Chemistry}

General information: All commercially available chemicals were used as purchased. Anhydrous reactions were run under a positive pressure of dry $\mathrm{N}_{2}$. Thin-layer chromatography (TLC) was carried out using Merck TLC plates: silica gel $60 \mathrm{~F}_{254}$. Chromatographic purifications were performed on columns packed with Merck 60 silica gel, 23-400 mesh, for the flash technique. ${ }^{1} \mathrm{H}$ and ${ }^{13} \mathrm{C}$ NMR spectra were recorded at $400 \mathrm{MHz}$ on a Bruker Avance DPX400 spectrometer. Chemical shifts are reported relative to $\left(\mathrm{CH}_{3}\right)_{4} \mathrm{Si}$ at $\delta=$ $0.00 \mathrm{ppm}$. Melting points were measured using a Gallenkamp melting point apparatus and are uncorrected. Elemental analyses were performed on a PerkinElmer PE 2004 elemental analyzer, and the data for $\mathrm{C}, \mathrm{H}$, and $\mathrm{N}$ are within $0.4 \%$ of theoretical values.

HPLC and MS analysis: The purity of the tested compounds was assessed by reversed-phase liquid chromatography and a mass spectrometer (Agilent series 1100 LC/MSD) equipped with a UV detector $(\lambda=254 \mathrm{~nm})$ and an electrospray ionization (ESI) source. The LC elution method (using a Zorbax Eclipse XDB, $4.6 \times 150 \mathrm{~mm}$, $5 \mu \mathrm{m} \mathrm{C}_{8}$ column) involved the following: (compounds $8 \mathrm{a}$ and $9 \mathrm{a}-$ c) $T=25^{\circ} \mathrm{C}$, mobile phase composed of A) $60 \% \mathrm{CH}_{3} \mathrm{OH}$ and B) $40 \%$ $\mathrm{H}_{2} \mathrm{O}$ at a flow rate of $0.8 \mathrm{~mL} \mathrm{~min}^{-1}$; (compounds $12 \mathrm{a}-\mathrm{d}$ and $16 \mathrm{a}-\mathrm{n}$ ) $T=25^{\circ} \mathrm{C}$, mobile phase composed of A) $70 \% \mathrm{CH}_{3} \mathrm{CN}$ and B) $30 \%$ $\mathrm{H}_{2} \mathrm{O}$ with $0.5 \%$ formic acid at a flow rate of $1.0 \mathrm{~mL} \mathrm{~min}^{-1}$; (all solvents were HPLC grade, Sigma Aldrich). All analyzed compounds meet $>95 \%$ purity criteria. MS data were obtained using an Agilent $1100 \mathrm{LC} / \mathrm{MSD}$ VL system (G1946C) with a $0.4 \mathrm{~mL} \mathrm{~min}^{-1}$ flow rate using a binary solvent system of $95: 5 \mathrm{CH}_{3} \mathrm{OH} / \mathrm{H}_{2} \mathrm{O}$. UV detection was monitored at $\lambda=254 \mathrm{~nm}$. Mass spectra were acquired in negative mode scanning over the mass range of 50-1500 Da. The following ion source parameters were used: drying gas flow,

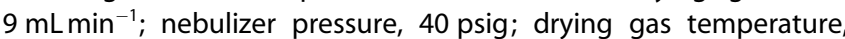
$350^{\circ} \mathrm{C}$

Microwave irradiation experiments: Microwave reactions were conducted using a CEM Discover Synthesis Unit (CEM Corp., Matthews, NC, USA). The instrument consists of a continuous focused microwave power delivery system with operator-selectable power output from 0 to $300 \mathrm{~W}$. The temperature of the contents of the vessel was monitored with a calibrated IR temperature control mounted under the reaction vessel. All experiments were performed using a stirring option, whereby the contents of the vessel are stirred by a rotating magnetic plate located below the floor of the microwave cavity and a Teflon-coated magnetic stir bar in the vessel.

Methyl 4-(5-formylfuran-2-yl)-2-hydroxybenzoate (3): Methyl-4iodosalycilate $1(1.00 \mathrm{mmol})$ and 5 -formyl-2-furan boronic acid 2 $(1.30 \mathrm{mmol})$ were dissolved in $10 \mathrm{~mL} \mathrm{DMF}$ and $15 \mathrm{~mL} \mathrm{EtOH}$. The reaction mixture was stirred for 10 min under $\mathrm{N}_{2}$, then $\mathrm{Pd}\left(\mathrm{PPh}_{3}\right)_{2} \mathrm{Cl}_{2}$ $(0.10 \mathrm{mmol})$ and a solution of $\mathrm{Na}_{2} \mathrm{CO}_{3}(2 \mathrm{M}, 6 \mathrm{mmol})$ were added to the reaction mixture, and the light-orange suspension was stirred under $\mathrm{N}_{2}$ at room temperature. After $1 \mathrm{~h}$ the reaction went to com- pletion (TLC) and was quenched with $\mathrm{H}_{2} \mathrm{O}$ and $2 \mathrm{~N} \mathrm{HCl}$, then EtOAc was added, and the mixture was stirred until the two layers became clear. The aqueous layer was extracted three times with EtOAc, then the organic layers were washed with $\mathrm{H}_{2} \mathrm{O}$ and brine, dried over $\mathrm{Na}_{2} \mathrm{SO}_{4}$, filtered, and evaporated under reduced pressure. The crude product was purified by flash chromatography using $\mathrm{PE} / \mathrm{EtOAC}=7: 3$ as eluent to yield the desired product 3 as a light-orange solid (yield: $99 \%$ ); $\mathrm{mp}=150^{\circ} \mathrm{C}$ (decomposition); ${ }^{1} \mathrm{H} \mathrm{NMR}\left(\mathrm{CDCl}_{3}, 400 \mathrm{MHz}\right): \delta=10.84(\mathrm{~s}, 1 \mathrm{H}), 9.69(\mathrm{~s}, 1 \mathrm{H}), 7.91-7.88$ $(\mathrm{d}, 1 \mathrm{H}, J=12 \mathrm{~Hz}), 7.40-7.39(\mathrm{~d}, 1 \mathrm{H}, J=4 \mathrm{~Hz}), 7.35-7.32(\mathrm{~m}, 3 \mathrm{H})$ 6.94-6.93 (d, $1 \mathrm{H}, J=4 \mathrm{~Hz}), 3.97(\mathrm{~s}, 3 \mathrm{H}) ;{ }^{13} \mathrm{C} \mathrm{NMR}\left(\mathrm{CDCl}_{3}, 100 \mathrm{MHz}\right)$ : $\delta=177.47,161.69,157.37,152.53,135.17,130.58,122.56,115.74$ 113.73, 112.82, 109.84, 52.40, 29.59; MS (ES): $\mathrm{m} / \mathrm{z} 245.0[M-1]^{-}$; Anal. $\left(\mathrm{C}_{13} \mathrm{H}_{10} \mathrm{O}_{5}\right) \mathrm{C}, \mathrm{H}, \mathrm{N}$.

4-(5-Formylfuran-2-yl)-2-hydroxybenzoic acid (4): Compound 3 $(1.73 \mathrm{mmol})$ was dissolved in $30 \mathrm{~mL} \mathrm{CH} \mathrm{CH}_{3} \mathrm{OH}$, then a solution of $\mathrm{NaOH}(1 \mathrm{M}, 5.00 \mathrm{mmol})$ was added dropwise and at a rate of $1 \mathrm{~mL} \mathrm{~h}^{-1}$ to the reaction mixture. After the first addition of $\mathrm{NaOH}$ solution, the reaction mixture was heated at reflux, and the following additions were performed at this temperature. The reaction mixture was stirred overnight until completion (TLC). Organic solvent was removed under reduced pressure, then some $\mathrm{H}_{2} \mathrm{O}$ $(\sim 10 \mathrm{~mL})$ was added, and the aqueous layer was extracted three times with $\mathrm{Et}_{2} \mathrm{O}$; the aqueous layer was then acidified to $\mathrm{pH} 1$ with $\mathrm{HCl}(6 \mathrm{~N})$ and a precipitate appeared. The desired product 4 was obtained as a brown-red solid (yield: $93 \%$ ); $\mathrm{mp}=230^{\circ} \mathrm{C}$ (decomposition); ${ }^{1} \mathrm{H}$ NMR (DMSO, $\left.400 \mathrm{MHz}\right): \delta=9.63(\mathrm{~s}, 1 \mathrm{H}), 7.88-7.86(\mathrm{~d}$, $1 \mathrm{H}, J=8 \mathrm{~Hz}), \quad 7.66-7.65(\mathrm{~d}, \quad 1 \mathrm{H}, \quad J=4 \mathrm{~Hz}), 7.45-7.39(\mathrm{~m}, \quad 3 \mathrm{H})$; ${ }^{13} \mathrm{C}$ NMR (DMSO， $100 \mathrm{MHz}$ ): $\delta=178.72,171.68,161.69,156.82$, 152.63, 135.11, 131.72, 125.14, 116.02, 114.06, 113.29, 111.53; MS (ES): $m / z 231.0[M-1]^{-}$; Anal. $\left(\mathrm{C}_{12} \mathrm{H}_{8} \mathrm{O}_{5}\right) \mathrm{C}, \mathrm{H}, \mathrm{N}$.

Triisopropylsilyl 4-(5-formylfuran-2-yl)-2-(triisopropylsilyloxy)benzoate (5): Compound $4(0.23 \mathrm{mmol})$ was dissolved in $1.5 \mathrm{~mL}$ dry DMF, then imidazole was added $(1.16 \mathrm{mmol})$, and the reaction mixture was cooled to $0^{\circ} \mathrm{C}$ before adding triisopropylsilyl chloride $(1.07 \mathrm{mmol})$. The reaction mixture was heated at $60^{\circ} \mathrm{C}$ for $17 \mathrm{~h}$. $\mathrm{H}_{2} \mathrm{O}$ was added, and the aqueous layer was extracted three times with EtOAc; the organic layers were then washed with brine, dried over $\mathrm{Na}_{2} \mathrm{SO}_{4}$, filtered, and evaporated under reduced pressure. The crude product was purified by flash chromatography using $\mathrm{PE} /$ EtOAc $=95: 5$ as eluent and then with a kugelrohr apparatus to yield the desired product as a yellow oil (yield: $35 \%$ ). ${ }^{1} \mathrm{H}$ NMR $\left(\mathrm{CDCl}_{3}, 400 \mathrm{MHz}\right): \delta=9.69(\mathrm{~s}, 1 \mathrm{H}), 7.85-7.83(\mathrm{~d}, 1 \mathrm{H}, J=8 \mathrm{~Hz}), 7.39$ $7.37(\mathrm{~d}, 1 \mathrm{H}, J=8 \mathrm{~Hz}), 7.32-7.31(\mathrm{~m}, 2 \mathrm{H}), 6.85-6.84(\mathrm{~d}, 1 \mathrm{H}, J=4 \mathrm{~Hz})$ 1.43-1.33 (m, 6H), 1.15-1.13 (m, 36 H) ; ${ }^{13} \mathrm{C}$ NMR $\left(\mathrm{CDCl}_{3}, 100 \mathrm{MHz}\right)$ : $\delta=177.34,163.81,157.85,156.91,152.57,132.92,132.41,124.41$ 122.49, 117.00, 109.06, 18.01, 17.90, 13.11, 12.08; MS (ES): $\mathrm{m} / \mathrm{z} 387.1$ $[M-157]^{-}, 566.8[M+23]^{+}$; Anal. $\left(\mathrm{C}_{30} \mathrm{H}_{48} \mathrm{O}_{5} \mathrm{Si}_{2}\right) \mathrm{C}, \mathrm{H}, \mathrm{N}$.

General procedure for the synthesis of compounds $7 \mathrm{a}-\mathrm{c}$ : Compound $5(0.30 \mathrm{mmol})$ was dissolved in $10 \mathrm{~mL}$ dry THF; then the solution was cooled to $-78^{\circ} \mathrm{C}$ and Grignard reagent solution in THF $(0.48 \mathrm{mmol})$ was added dropwise. The reaction mixture was stirred at $-78^{\circ} \mathrm{C}$ for $1 \mathrm{~h}$ until completion (TLC). A saturated solution of $\mathrm{NH}_{4} \mathrm{Cl}$ was added to the reaction mixture, then the aqueous layer was extracted three times with EtOAc, then the organic layers were washed with brine, dried over $\mathrm{Na}_{2} \mathrm{SO}_{4}$, filtered and evaporated under reduced pressure. The crude products were purified by flash chromatography using $\mathrm{PE} / \mathrm{EtOAC}=9: 1$ as eluent to yield desired products as colorless oils.

Triisopropylsilyl 4-(5-((4-fluorophenyl)(hydroxy)methyl)furan-2yl)-2-(triisopropylsilyloxy)benzoate (7a): (yield: $73 \%$ ); ${ }^{1} \mathrm{H}$ NMR 
$\left(\mathrm{CDCl}_{3}, 400 \mathrm{MHz}\right): \delta=7.79-7.77(\mathrm{~d}, 1 \mathrm{H}, J=8 \mathrm{~Hz}), 7.47-7.44(\mathrm{~m}$ $2 \mathrm{H}), 7.18-1.16(\mathrm{~d}, 1 \mathrm{H}, J=8 \mathrm{~Hz}), 7.12(\mathrm{~s}, 1 \mathrm{H}), 7.09-7.04(\mathrm{~m}, 2 \mathrm{H})$ 6.61-6.60 (d, $1 \mathrm{H}, J=4 \mathrm{~Hz}), 6.27-6.26(\mathrm{~d}, 1 \mathrm{H}, J=4 \mathrm{~Hz}), 5.85(\mathrm{~s}, 1 \mathrm{H})$, $1.42-1.29(\mathrm{~m}, 6 \mathrm{H}), 1.15-1.12(\mathrm{~m}, 36 \mathrm{H}) ;{ }^{13} \mathrm{C}$ NMR $\left(\mathrm{CDCl}_{3}, 100 \mathrm{MHz}\right)$ : $\delta=164.01,163.69,156.79,156.03,152.79,136.40,134.40,132.19$, 128.31, 128.23, 122.16, 115.38, 115.15, 109.42, 107.26, 69.58, 17.91, 17.82, 12.97, 11.98; MS (ES): $\mathrm{m} / z$ 483.1 [M-157] $]^{-}$; Anal. $\left(\mathrm{C}_{36} \mathrm{H}_{53} \mathrm{FO}_{5} \mathrm{Si}_{2}\right) \mathrm{C}, \mathrm{H}, \mathrm{N}$.

Triisopropylsilyl 4-(5-((3-fluorophenyl)(hydroxy)methyl)furan-2yl)-2-(triisopropylsilyloxy)benzoate (7b): (yield: 63\%); ${ }^{1} \mathrm{H}$ NMR $\left(\mathrm{CDCl}_{3}, 400 \mathrm{MHz}\right): \delta=7.79-7.77(\mathrm{~d}, J=8 \mathrm{~Hz}, 1 \mathrm{H}), 7.33(\mathrm{~m}, 1 \mathrm{H}), 7.24$ $(\mathrm{m}, 1 \mathrm{H}), 7.18-7.16(\mathrm{~d}, J=8 \mathrm{~Hz}, 1 \mathrm{H}), 7.13(\mathrm{~s}, 1 \mathrm{H}), 7.02(\mathrm{~m}, 1 \mathrm{H}), 6.61-$ $6.60(\mathrm{~d}, J=4 \mathrm{~Hz}, 1 \mathrm{H}), 6.30-6.29(\mathrm{~d}, J=4 \mathrm{~Hz}, 1 \mathrm{H}), 5.86(\mathrm{~s}, 1 \mathrm{H}), 2.62$ $(\mathrm{s}, 1 \mathrm{H}), 1.35(\mathrm{~m}, 6 \mathrm{H}), 1.10(\mathrm{~m}, 36 \mathrm{H}) ;{ }^{13} \mathrm{C} \mathrm{NMR}\left(\mathrm{CDCl}_{3}, 100 \mathrm{MHz}\right): \delta=$ $164.2,157.1,155.8,153.5,153.2,134.6,132.4,130.2,130.1,123.1$, 122.5, 115.7, 115.2, 113.9, 113.6, 109.9, 107.5, 69.8, 18.2, 18.1, 13.2, 12.2; MS (ES): $m / z 483.1[M-157]^{-}$; Anal. $\left(\mathrm{C}_{36} \mathrm{H}_{53} \mathrm{FO}_{5} \mathrm{Si}_{2}\right) \mathrm{C}, \mathrm{H}, \mathrm{N}$.

Triisopropylsilyl 4-(5-(biphenyl-3-yl(hydroxy)methyl)furan-2-yl)2-(triisopropylsilyloxy)benzoate (7c): (yield: $66 \%) ;{ }^{1} \mathrm{H}$ NMR $\left(\mathrm{CDCl}_{3 \prime}\right.$ $400 \mathrm{MHz}): \delta=7.80-7.78(\mathrm{~d}, 1 \mathrm{H}, J=8 \mathrm{~Hz}), 7.71(\mathrm{~s}, 1 \mathrm{H}), 7.61-7.57$ $(\mathrm{m}, 3 \mathrm{H}), 7.48-7.42(\mathrm{~m}, 4 \mathrm{H}), 7.37-7.35(\mathrm{~d}, 1 \mathrm{H}, J=8 \mathrm{~Hz}), 7.20-7.18(\mathrm{~d}$, $1 \mathrm{H}, J=8 \mathrm{~Hz}), 7.14(\mathrm{~s}, 1 \mathrm{H}), 6.62-6.61(\mathrm{~d}, 1 \mathrm{H}, J=4 \mathrm{~Hz}), 6.31-6.30(\mathrm{~d}$, $1 \mathrm{H}, J=4 \mathrm{~Hz}), 5.96(\mathrm{~s}, 1 \mathrm{H}), 1.44-1.27(\mathrm{~m}, 6 \mathrm{H}), 1.15-1.10(\mathrm{~m}, 36 \mathrm{H})$ ${ }^{13} \mathrm{CNMR} \quad\left(\mathrm{CDCl}_{3}, 100 \mathrm{MHz}\right): \delta=163.99,156.82,152.78,141.49$, $141.11,140.80,134.51,132.21,128.90,128.71,127.36,127.11$, $126.89,125.44,125.34,122.12,115.48,109.58,107.35,70.33,17.93$, 17.85, 12.97, 12.00; MS (ES): $m / z 541.2[M-157]^{-}, 721.3[M+23]^{+}$; Anal. $\left(\mathrm{C}_{42} \mathrm{H}_{58} \mathrm{O}_{5} \mathrm{Si}_{2}\right) \mathrm{C}, \mathrm{H}, \mathrm{N}$.

4-(5-((4-Fluorophenyl)(hydroxy)methyl)furan-2-yl)-2-hydroxybenzoic acid (8a): Compound 7 a $(0.12 \mathrm{mmol})$ was dissolved in $2 \mathrm{~mL}$ dry THF, then the solution was cooled to $0^{\circ} \mathrm{C}$. A solution of TBAF ( $1 \mathrm{M}$ in THF, $0.31 \mathrm{mmol}$ ) was added dropwise to the reaction mixture at $0^{\circ} \mathrm{C}$. The reaction mixture was allowed to warm to room temperature and stirred for $30 \mathrm{~min}$. EtOAc was added and the organic layer was washed three times with a saturated solution of $\mathrm{NH}_{4} \mathrm{Cl}$, then with brine, dried over $\mathrm{Na}_{2} \mathrm{SO}_{4}$ and evaporated under reduced pressure. The crude product was dissolved in a solution of $\mathrm{NaOH}(1 \mathrm{~N})$ and the aqueous layer was extracted three times with $\mathrm{Et}_{2} \mathrm{O}$. The aqueous layer was acidified until $\mathrm{pH} 1$ with $\mathrm{HCl}(6 \mathrm{~N})$ and extracted three times with EtOAc. The organic layers were washed with brine, dried over $\mathrm{Na}_{2} \mathrm{SO}_{4}$, filtered and evaporated under reduced pressure. The crude product was purified by flash chromatography using EtOAc with some drops of acetic acid as eluent to yield the desired product as a white solid (yield: $51 \%$ ); $\mathrm{mp}=162^{\circ} \mathrm{C}$ (decomposition); ${ }^{1} \mathrm{H}$ NMR (MeOD, $\left.400 \mathrm{MHz}\right): \delta=7.84-7.82(\mathrm{~d}, 1 \mathrm{H}$, $J=8 \mathrm{~Hz}), 7.51-7.48(\mathrm{~m}, 2 \mathrm{H}), 7.19-7.16(\mathrm{~m}, 2 \mathrm{H}), 7.12-7.08(\mathrm{~m}, 2 \mathrm{H})$, 6.84-6.83 (d, $1 \mathrm{H}, J=4 \mathrm{~Hz}), 6.25-6.24(\mathrm{~d}, 1 \mathrm{H}, J=4 \mathrm{~Hz}), 5.82(\mathrm{~s}, 1 \mathrm{H})$; MS (ES): $m / z 327.0[M-1]^{-}$; Anal. $\left(\mathrm{C}_{18} \mathrm{H}_{13} \mathrm{FO}_{5}\right) \mathrm{C}, \mathrm{H}, \mathrm{N}$.

General procedure for the synthesis of compounds $9 \mathrm{a}-\mathrm{c}$ : Nal $(0.69 \mathrm{mmol})$ was dissolved in $1 \mathrm{~mL}$ dry $\mathrm{CH}_{3} \mathrm{CN}$ and $\mathrm{TMSCl}$ $(0.69 \mathrm{mmol})$ was added, a white precipitate formed. Compound $7 \mathrm{a}-\mathrm{c}(0.12 \mathrm{mmol})$ was dissolved in $3 \mathrm{~mL}$ dry $\mathrm{CH}_{3} \mathrm{CN}$ and this solution was added with a double needle to the reaction mixture at room temperature. The reaction mixture was stirred $30 \mathrm{~min}$ at room temperature. $\mathrm{H}_{2} \mathrm{O}$ and EtOAc were added, layers were separated, and the aqueous layer was extracted three times with $\mathrm{EtOAc}$, then organic layers were washed with brine, dried over $\mathrm{Na}_{2} \mathrm{SO}_{4}$, filtered and evaporated under reduced pressure. The crude products were purified by flash chromatography using $\mathrm{PE} / \mathrm{EtOAC}=$ 9:1 as eluent to obtain the desired products as white solids.
4-(5-(4-Fluorobenzyl)furan-2-yl)-2-hydroxybenzoic acid (9a): (yield 83\%); $\mathrm{mp}=202^{\circ} \mathrm{C}$ (decomposition); ${ }^{1} \mathrm{H} N M R \quad\left(\left(\mathrm{CD}_{3}\right)_{2} \mathrm{CO}\right.$, $400 \mathrm{MHz}): \delta=7.94-7.92(\mathrm{~d}, 1 \mathrm{H}, J=8 \mathrm{~Hz}), 7.46-7.43(\mathrm{~m}, 2 \mathrm{H}), 7.30$ $7.28(\mathrm{~d}, 1 \mathrm{H}, J=8 \mathrm{~Hz}), 7.25(\mathrm{~s}, 1 \mathrm{H}), 7.17-7.15(\mathrm{~m}, 2 \mathrm{H}), 7.03-7.02(\mathrm{~d}$, $1 \mathrm{H}, J=4 \mathrm{~Hz}), 6.32-6.31(\mathrm{~d}, 1 \mathrm{H}, J=4 \mathrm{~Hz}), 4.15(\mathrm{~s}, 2 \mathrm{H}) ;{ }^{13} \mathrm{C}$ NMR $\left(\left(\mathrm{CD}_{3}\right)_{2} \mathrm{CO}, 100 \mathrm{MHz}\right): \delta=171.42,162.77,162.41,156.03,151.36$, $137.53,134.02,130.87,130.44,130.36,115.12,114.90,114.03$, 110.71, 110.45, 109.37, 108.90, 33.11; MS (ES): $\mathrm{m} / \mathrm{z} 311.0[\mathrm{M}-1]^{-}$; Anal. $\left(\mathrm{C}_{18} \mathrm{H}_{13} \mathrm{FO}_{4}\right) \mathrm{C}, \mathrm{H}, \mathrm{N}$.

4-(5-((3-Fluorophenyl)(hydroxy)methyl)furan-2-yl)-2-hydroxybenzoic acid (9b): (yield: $41 \%$ ); $\mathrm{mp}=177^{\circ} \mathrm{C}$ (decomposition); ${ }^{1} \mathrm{H}$ NMR (MeOD, $400 \mathrm{MHz}): \delta=7.83-7.81(\mathrm{~d}, 1 \mathrm{H}, J=8 \mathrm{~Hz}), 7.31(\mathrm{~m}, 1 \mathrm{H})$, $7.12(\mathrm{~m}, 3 \mathrm{H}), 7.02-7.00(\mathrm{~d}, 1 \mathrm{H}, J=8 \mathrm{~Hz}), 6.94(\mathrm{~m}, 1 \mathrm{H}), 6.82-6.81(\mathrm{~d}$, $1 \mathrm{H}, J=4 \mathrm{~Hz}), 6.20-6.19(\mathrm{~d}, 1 \mathrm{H}, J=4 \mathrm{~Hz}), 4.05(\mathrm{~s}, 2 \mathrm{H}) ;{ }^{13} \mathrm{C} \mathrm{NMR}$ (MeOD, $100 \mathrm{MHz}$ ): $\delta=164.10,162.00,161.67,154.96,151.69$, $140.57,136.92,130.64,129.81,124.14,115.07,113.62,112.95$, 112.74, 110.35, 108.66, 108.37, 33.42; MS (ES) $=m / z 311.0[M-1]^{-}$; Anal. $\left(\mathrm{C}_{18} \mathrm{H}_{13} \mathrm{FO}_{5}\right) \mathrm{C}, \mathrm{H}, \mathrm{N}$.

4-(5-(Biphenyl-3-ylmethyl)furan-2-yl)-2-hydroxybenzoic acid (9c): (yield: $50 \%) ; \quad m p=189^{\circ} \mathrm{C}$ (decomposition); ${ }^{1} \mathrm{H} N M R$ (MeOD, $400 \mathrm{MHz}): \delta=7.82-7.80(\mathrm{~d}, 1 \mathrm{H}, J=8 \mathrm{~Hz}), 7.58-7.56(\mathrm{~d}, 1 \mathrm{H}, J=$ $8 \mathrm{~Hz}), 7.53(\mathrm{~s}, 1 \mathrm{H}), 7.48-7.46(\mathrm{~d}, 1 \mathrm{H}, J=8 \mathrm{~Hz}), 7.42-7.36(\mathrm{~m}, 2 \mathrm{H})$, 7.32-7.30 (d, $1 \mathrm{H}, J=8 \mathrm{~Hz}), 7.27-7.25(\mathrm{~d}, 1 \mathrm{H}, J=8 \mathrm{~Hz}), 7.14-7.12(\mathrm{~m}$, $2 \mathrm{H}), 6.79-6.78(\mathrm{~d}, 1 \mathrm{H}, J=4 \mathrm{~Hz}), 6.18-6.17(\mathrm{~d}, 1 \mathrm{H}, J=4 \mathrm{~Hz}), 4.09(\mathrm{~s}$, $2 \mathrm{H}$ ); ${ }^{13} \mathrm{C}$ NMR (DMSO, $\left.100 \mathrm{MHz}\right): \delta=172.02,162.08,156.06,151.21$, $140.84,140.44,138.91,136.71,131.37,129.55,129.32,128.12$, 127.87, 127.48, 127.07, 125.34, 114.14, 112.37, 110.78, 110.10, 109.63, 34.15; MS (ES): $\mathrm{m} / \mathrm{z} 369.1[\mathrm{M}-1]^{-}$; Anal. $\left(\mathrm{C}_{24} \mathrm{H}_{18} \mathrm{O}_{4}\right) \mathrm{C}, \mathrm{H}, \mathrm{N}$.

General procedure for the synthesis of compounds $12 \mathrm{a}-\mathrm{d}$ : To a suspension of rhodanine $(0.13 \mathrm{mmol})$ in $\mathrm{EtOH}$, 5-aryl-2-furaldehyde $4(0.13 \mathrm{mmol})$ and amine $(0.39 \mathrm{mmol})$ were added. The reaction mixture was heated by microwave irradiation at $150^{\circ} \mathrm{C}$ for $20 \mathrm{~min}$. The reaction vessel was allowed to cool to room temperature and a drop of $\mathrm{HCl}(2 \mathrm{~N})$ was added. The precipitated solid was filtered off, washed with $\mathrm{H}_{2} \mathrm{O}$ and $\mathrm{EtOH}$, and dried under vacuum.

(Z)-2-Hydroxy-4-(5-((2-morpholino-4-oxothiazol-5(4H)-ylidene)methyl)furan-2-yl)benzoic acid (12a): (yield: $75 \%$ ); Yellow solid; $\mathrm{mp}=267^{\circ} \mathrm{C}$ (decomposition); ${ }^{1} \mathrm{H}$ NMR (DMSO, $400 \mathrm{MHz}$ ): $\delta=7.91-$ $7.89(\mathrm{~d}, 1 \mathrm{H}, J=8 \mathrm{~Hz}), 7.50(\mathrm{~s}, 1 \mathrm{H}), 7.43-7.36(\mathrm{~m}, 3 \mathrm{H}), 7.16-7.15(\mathrm{~d}$, $1 \mathrm{H}, J=4 \mathrm{~Hz}), 3.93-3.91(\mathrm{~m}, 2 \mathrm{H}), 3.80-3.78(\mathrm{~m}, 2 \mathrm{H}), 3.74-3.71(\mathrm{~m}$, $4 \mathrm{H}) ;{ }^{13} \mathrm{C}$ NMR (DMSO, $100 \mathrm{MHz}$ ): $\delta=179.10,175.06,171.69,161.74$, $154.74,150.67,135.53,131.77,127.02,119.42,116.47,115.35$, 113.06, 112.47, 112.12, 66.06, 65.89, 48.82, 48.68; MS (ES): $\mathrm{m} / \mathrm{z} 399.0$ $[M-1]^{-}$; Anal. $\left(\mathrm{C}_{19} \mathrm{H}_{16} \mathrm{~N}_{2} \mathrm{O}_{6} \mathrm{~S}\right) \mathrm{C}, \mathrm{H}, \mathrm{N}$.

(Z)-2-Hydroxy-4-(5-((4-oxo-2-thiomorpholinothiazol-5(4H)-ylidene)methyl)furan-2-yl)benzoic acid (12b): (yield: $31 \%$ ); Yellow solid; $\mathrm{mp}=217^{\circ} \mathrm{C}$ (decomposition); ${ }^{1} \mathrm{H}$ NMR (DMSO, $400 \mathrm{MHz}$ ): $\delta=$ 7.92-7.90 (d, $1 \mathrm{H}, J=8 \mathrm{~Hz}), 7.50(\mathrm{~s}, 1 \mathrm{H}), 7.43-7.36(\mathrm{~m}, 3 \mathrm{H}), 7.16-$ $7.15(\mathrm{~d}, 1 \mathrm{H}, J=4 \mathrm{~Hz}), 4.19-4.17(\mathrm{~m}, 2 \mathrm{H}), 3.96-3.94(\mathrm{~m}, 2 \mathrm{H}), 2.87-$ $2.85(\mathrm{~m}, 2 \mathrm{H}), 2.79-2.77(\mathrm{~m}, 2 \mathrm{H}) ;{ }^{13} \mathrm{C}$ NMR (DMSO, $\left.100 \mathrm{MHz}\right): \delta=$ $179.18,175.01,171.71,161.76,154.78,150.67,135.53,131.77$, 127.02, 119.43, 116.53, 115.35, 113.08, 112.47, 112.13, 51.85, 51.22, 27.40, 26.87; MS (ES): $\mathrm{m} / \mathrm{z} 415.0[\mathrm{M}-1]^{-}$; Anal. $\left(\mathrm{C}_{19} \mathrm{H}_{16} \mathrm{~N}_{2} \mathrm{O}_{5} \mathrm{~S}_{2}\right) \mathrm{C}, \mathrm{H}$, N.

(Z)-2-Hydroxy-4-(5-((2-(4-methylpiperazin-1-yl)-4-oxothiazol5(4H)-ylidene)methyl)furan-2-yl)benzoic acid (12c): (yield: $76 \%$ ); Yellow solid; $\mathrm{mp}=265^{\circ} \mathrm{C}$ (decomposition); ${ }^{1} \mathrm{H}$ NMR (DMSO, $400 \mathrm{MHz}): \delta=7.90-7.88(\mathrm{~d}, 1 \mathrm{H}, J=8 \mathrm{~Hz}), 7.52(\mathrm{~s}, 1 \mathrm{H}), 7.39-7.35$ $(\mathrm{m}, 3 \mathrm{H}), 7.16-7.15(\mathrm{~d}, 1 \mathrm{H}, J=4 \mathrm{~Hz}), 4.20-4.18(\mathrm{~m}, 2 \mathrm{H}), 4.02-4.00$ $(\mathrm{m}, 2 \mathrm{H}), 3.39-3.33(\mathrm{~m}, 4 \mathrm{H}) 2.78(\mathrm{~s}, 3 \mathrm{H}) ;{ }^{13} \mathrm{C}$ NMR (DMSO, $100 \mathrm{MHz}$ ): 
$\delta=179.33,175.71,171.82,161.84,155.16,150.29,134.94,131.76$ 126.67, 120.08, 117.14, 115.11, 114.06, 112.35, 112.11, 51.94, 51.70, 45.48, 44.92, 42.54; MS (ES): $\mathrm{m} / z 412.0[\mathrm{M}-1]^{-}$; Anal. $\left(\mathrm{C}_{20} \mathrm{H}_{19} \mathrm{~N}_{3} \mathrm{O}_{5} \mathrm{~S}\right)$ $\mathrm{C}, \mathrm{H}, \mathrm{N}$.

(Z)-4-(5-((2-(Benzylamino)-4-oxothiazol-5(4H)-ylidene)methyl)furan-2-yl)-2-hydroxybenzoic acid (12d): (yield: $73 \%$ ); Yellow solid; $\mathrm{mp}=279^{\circ} \mathrm{C}$ (decomposition); ${ }^{1} \mathrm{H}$ NMR (DMSO, $\left.400 \mathrm{MHz}\right): \delta=7.84$ $7.82(\mathrm{~d}, 1 \mathrm{H}, J=8 \mathrm{~Hz}), 7.46(\mathrm{~s}, 1 \mathrm{H}), 7.39-7.30(\mathrm{~m}, 8 \mathrm{H}), 7.12-7.11(\mathrm{~d}$, $1 \mathrm{H}, J=4 \mathrm{~Hz}$ ), $4.73(\mathrm{~s}, 2 \mathrm{H}) ;{ }^{13} \mathrm{C}$ NMR (DMSO, $\left.100 \mathrm{MHz}\right): \delta=179.12$, $174.24,171.74,161.92,154.46,150.83,137.44,135.62,131.44$, $128.95,128.12,127.94,127.38,119.12,115.91,115.32,112.85$, 112.49, 111.83, 48.26; MS (ES): $\mathrm{m} / z \quad 419.0 \quad[M-1]^{-}$; Anal. $\left(\mathrm{C}_{22} \mathrm{H}_{16} \mathrm{~N}_{2} \mathrm{O}_{5} \mathrm{~S}\right) \mathrm{C}, \mathrm{H}, \mathrm{N}$.

General procedure for the synthesis of compounds $16 \mathrm{a}-\mathbf{n}$ : To a solution of bis(carboxymethyl)trithiocarbonate $13(0.22 \mathrm{mmol})$ in DME $(1.0 \mathrm{~mL})$ were added $\mathrm{Et}_{3} \mathrm{~N}(0.22 \mathrm{mmol})$ and the opportune amine $\left(\mathrm{R}_{1} \mathrm{NH}_{2}, 0.22 \mathrm{mmol}\right)$. The reaction mixture was heated at $90^{\circ} \mathrm{C}$ for 10 min under microwave irradiation. After this time, the 5-aryl-2-furaldehyde $4(0.22 \mathrm{mmol})$ was added, and the mixture was heated at $110^{\circ} \mathrm{C}$ for $5 \mathrm{~min}$ under microwave irradiation. The reaction mixture was evaporated to dryness, and the residue was resuspended with $\mathrm{CH}_{3} \mathrm{OH}(\sim 2 \mathrm{~mL})$ and a drop of $\mathrm{HCl} 2 \mathrm{~N}$; the final rhodanine derivatives were obtained as a pure precipitate, isolated by filtration, washed with $\mathrm{H}_{2} \mathrm{O}$ and hexane, and finally dried under high vacuum.

(Z)-4-(5-((3-(4-Fluorobenzyl)-4-oxo-2-thioxothiazolidin-5-ylidene)methyl)furan-2-yl)-2-hydroxybenzoic acid (16a): (yield: 35\%); Yellow solid; $\mathrm{mp}=260^{\circ} \mathrm{C}$ (decomposition); ${ }^{1} \mathrm{H} N M R \quad$ (DMSO, $400 \mathrm{MHz}): \delta=7.86-7.84(\mathrm{~d}, 1 \mathrm{H}, J=8 \mathrm{~Hz}), 7.69(\mathrm{~s}, 1 \mathrm{H}), 7.39-7.37$ $(\mathrm{m}, 4 \mathrm{H}), 7.27-7.25(\mathrm{~m}, 2 \mathrm{H}), 7.18-7.14(\mathrm{~m}, 2 \mathrm{H}), 5.21(\mathrm{~s}, 2 \mathrm{H}) ;{ }^{13} \mathrm{C} N M R$ (DMSO, $100 \mathrm{MHz}): \delta=194.23,171.67,166.97,162.16,157.19$, $150.33,134.30,131.72,131.63,130.53,130.41,125.94,123.61$, $119.68,119.01,118.79,116.01,115.75,115.57,115.21,114.98,112.88$, 112.66, 46.81; MS (ES): $m / z 454.0[M-1]^{-}$; Anal. $\left(\mathrm{C}_{22} \mathrm{H}_{14} \mathrm{FNO}_{5} \mathrm{~S}_{2}\right) \mathrm{C}, \mathrm{H}$, N.

(Z)-4-(5-((3-Benzyl-4-oxo-2-thioxothiazolidin-5-ylidene)methyl)furan-2-yl)-2-hydroxybenzoic acid (16 b): (yield: 75\%); Yellow solid; $\mathrm{mp}=275^{\circ} \mathrm{C}$ (decomposition); ${ }^{1} \mathrm{H}$ NMR (DMSO, $400 \mathrm{MHz}$ ): $\delta=$ 7.90-7.88 (d, $1 \mathrm{H}, J=8 \mathrm{~Hz}), 7.68(\mathrm{~s}, 1 \mathrm{H}), 7.45-7.44(\mathrm{~d}, 1 \mathrm{H}, J=4 \mathrm{~Hz})$, 7.36-7.27 (m, 8H), $5.22(\mathrm{~s}, 2 \mathrm{H}) ;{ }^{13} \mathrm{C}$ NMR (DMSO, $\left.100 \mathrm{MHz}\right): \delta=$ $194.21,171.71,166.96,161.90,156.90,150.43,135.34,134.72$, $131.80,128.94,128.02,123.48,119.85,118.92,118.78,115.51$, 113.98, 113.11, 112.94, 112.50, 112.36, 47.49; MS (ES): $m / z 435.9 .0$ $[\mathrm{M}-1]^{-}$; Anal. $\left(\mathrm{C}_{22} \mathrm{H}_{15} \mathrm{NO}_{5} \mathrm{~S}_{2}\right) \mathrm{C}, \mathrm{H}, \mathrm{N}$.

(Z)-2-Hydroxy-4-(5-((3-(3-methoxybenzyl)-4-oxo-2-thioxothiazolidin-5-ylidene)methyl)furan-2-yl)benzoic acid (16c): (yield: $41 \%$; Yellow solid; $\mathrm{mp}=177^{\circ} \mathrm{C}$ (decomposition); ${ }^{1} \mathrm{H} N M R$ (DMSO, $400 \mathrm{MHz}): \delta=7.93-7.91(\mathrm{~d}, 1 \mathrm{H}, J=8 \mathrm{~Hz}), 7.71(\mathrm{~s}, 1 \mathrm{H}), 7.48-7.47(\mathrm{~d}$, $1 \mathrm{H}, J=4 \mathrm{~Hz}), 7.40-7.37(\mathrm{~m}, 3 \mathrm{H}), 7.26-7.22(\mathrm{~m}, 1 \mathrm{H}), 6.88-6.84(\mathrm{~s}$, $2 \mathrm{H}), 3.72(\mathrm{~s}, 3 \mathrm{H}) ;{ }^{13} \mathrm{C}$ NMR (DMSO, $\left.100 \mathrm{MHz}\right): \delta=194.29,171.71$, $168.10,166.98,161.90,159.72,156.83,150.51,136.82,134.87$, $131.85,130.09,123.40,119.92,118.89,115.56,113.75,113.30$, 113.14, 112.47, 55.43, 47.41; MS (ES): $m / z \quad 466.0[M-1]^{-}$; Anal. $\left(\mathrm{C}_{23} \mathrm{H}_{17} \mathrm{NO}_{6} \mathrm{~S}_{2}\right) \mathrm{C}, \mathrm{H}, \mathrm{N}$.

(Z)-4-(5-((3-(Benzo[d][1,3]dioxol-5-ylmethyl)-4-oxo-2-thioxothiazolidin-5-ylidene)methyl)furan-2-yl)-2-hydroxybenzoic acid (16d): (yield: $49 \%$ ); Orange solid; $\mathrm{mp}=283^{\circ} \mathrm{C}$ (decomposition); ${ }^{1} \mathrm{H}$ NMR (DMSO, $\left.400 \mathrm{MHz}\right): \delta=7.92-7.90(\mathrm{~d}, 1 \mathrm{H}, J=8 \mathrm{~Hz}), 7.67$ (s, $1 \mathrm{H}), 7.43-7.34(\mathrm{~m}, 4 \mathrm{H}), 6.91(\mathrm{~s}, 1 \mathrm{H}), 6.84(\mathrm{~s}, 2 \mathrm{H}), 5.97(\mathrm{~s}, 2 \mathrm{H}), 5.14$ $(\mathrm{s}, 2 \mathrm{H}) ;{ }^{13} \mathrm{C}$ NMR (DMSO, $\left.100 \mathrm{MHz}\right): \delta=194.18,171.72,166.97$,
$161.89,156.87,150.45,147.69,147.21,138.05,134.73,131.75$ $129.01,122.31,121.56,119.90,113.90,109.35,109.01,108.52$, 108.20, 101.49, 101.09, 47.46; MS (ES): $\mathrm{m} / \mathrm{z} 480.0[M-1]^{-}$; Anal. $\left(\mathrm{C}_{23} \mathrm{H}_{15} \mathrm{NO}_{7} \mathrm{~S}_{2}\right) \mathrm{C}, \mathrm{H}, \mathrm{N}$.

(Z)-2-Hydroxy-4-(5-((4-oxo-3-propyl-2-thioxothiazolidin-5-ylidene)methyl)furan-2-yl)benzoic acid (16e): (yield: 46\%); Yellowbrown solid; $m p=275^{\circ} \mathrm{C}$ (decomposition); ${ }^{1} \mathrm{H} N M R$ (DMSO, $400 \mathrm{MHz}): \delta=7.86-7.84(\mathrm{~d}, 1 \mathrm{H}, J=8 \mathrm{~Hz}), 7.55(\mathrm{~s}, 1 \mathrm{H}), 7.39-7.38(\mathrm{~d}$, $1 \mathrm{H}, J=4 \mathrm{~Hz}), 7.30-7.26(\mathrm{~m}, 3 \mathrm{H}), 3.95-3.92(\mathrm{t}, 2 \mathrm{H}, J=7.6 \mathrm{~Hz}), 1.66-$ $1.61(\mathrm{~m}, 2 \mathrm{H}), \quad 0.89-0.85(\mathrm{t}, 3 \mathrm{H}, J=7.2 \mathrm{~Hz}) ;{ }^{13} \mathrm{C} N M R$ (DMSO, $100 \mathrm{MHz}): \delta=194.23,171.77,166.90,161.78,156.60,150.45$ 134.89, 131.66, 123.00, 120.07, 118.28, 115.48, 113.41, 112.98, 112.36, 46.03, 20.28, 11.44; MS (ES): $\mathrm{m} / \mathrm{z} 388.0[M-1]^{-}$; Anal. $\left(\mathrm{C}_{18} \mathrm{H}_{15} \mathrm{NO}_{5} \mathrm{~S}_{2}\right) \mathrm{C}, \mathrm{H}, \mathrm{N}$.

(Z)-4-(5-((3-(Cyclopropylmethyl)-4-oxo-2-thioxothiazolidin-5-ylidene)methyl)furan-2-yl)-2-hydroxybenzoic acid (16 f): (yield: $50 \%$ ); Yellow solid; $\mathrm{mp}=276^{\circ} \mathrm{C}$ (decomposition); ${ }^{1} \mathrm{H}$ NMR (DMSO, $400 \mathrm{MHz}): \delta=7.87-7.85(\mathrm{~d}, 1 \mathrm{H}, J=8.4 \mathrm{~Hz}), 7.58(\mathrm{~s}, 1 \mathrm{H}), 7.40-7.39$ $(\mathrm{d}, 1 \mathrm{H}, J=3.2 \mathrm{~Hz}), 7.32-7.28(\mathrm{~m}, 3 \mathrm{H}), 3.89-3.87(\mathrm{~d}, 2 \mathrm{H}, J=7.2 \mathrm{~Hz})$, 1.20-1.30 (m, 1 H), 0.49-0.47 (d, 2H, J=7.2 Hz), 0.40-0.39 (d, 2H, $J=3.6 \mathrm{~Hz}$ ); ${ }^{13} \mathrm{C}$ NMR (DMSO, $100 \mathrm{MHz}$ ): $\delta=194.50,171.77,167.13$ $161.79,156.68,150.43,134.86,131.80,131.53,123.12,120.03$, 115.50, 113.46, 113.03, 112.39, 48.88, 9.58, 4.03; MS (ES): $\mathrm{m} / \mathrm{z} 400.0$ $[M-1]^{-}$; Anal. $\left(\mathrm{C}_{19} \mathrm{H}_{15} \mathrm{NO}_{5} \mathrm{~S}_{2}\right) \mathrm{C}, \mathrm{H}, \mathrm{N}$.

(Z)-2-Hydroxy-4-(5-((4-oxo-3-(prop-2-ynyl)-2-thioxothiazolidin-5ylidene)methyl)furan-2-yl)benzoic acid (16 g): (yield: 15\%); Yellow solid; $\mathrm{mp}=269^{\circ} \mathrm{C}$ (decomposition); ${ }^{1} \mathrm{H}$ NMR (DMSO, $400 \mathrm{MHz}$ ): $\delta=$ 7.94-7.92 (d, $1 \mathrm{H}, J=8 \mathrm{~Hz}), 7.75(\mathrm{~s}, 1 \mathrm{H}), 7.50-7.49(\mathrm{~d}, 1 \mathrm{H}, J=4 \mathrm{~Hz})$, 7.41-7.38 (m, 3H), $4.78(\mathrm{~s}, 2 \mathrm{H}), 3.31(\mathrm{~s}, 1 \mathrm{H}) ;{ }^{13} \mathrm{C}$ NMR (DMSO, $100 \mathrm{MHz}): \delta=193.13,171.70,165.95,161.84,156.95,150.43$, 134.83, 131.88, 123.65, 119.59, 119.16, 115.61, 113.84, 113.17, 112.52, 77.08, 75.05, 33.87; MS (ES): $\mathrm{m} / \mathrm{z} 384.0[M-1]^{-}$; Anal. $\left(\mathrm{C}_{18} \mathrm{H}_{15} \mathrm{NO}_{5} \mathrm{~S}_{2}\right) \mathrm{C}, \mathrm{H}, \mathrm{N}$.

(Z)-4-(5-((3-(4-Chlorobenzyl)-4-oxo-2-thioxothiazolidin-5-ylidene)methyl)furan-2-yl)-2-hydroxybenzoic acid (16h): (yield: 40\%); Yellow solid; $\mathrm{mp}=275^{\circ} \mathrm{C}$ (decomposition); ${ }^{1} \mathrm{H}$ NMR (DMSO, $400 \mathrm{MHz}): \delta=7.94-7.92(\mathrm{~d}, 1 \mathrm{H}, J=8 \mathrm{~Hz}), 7.73(\mathrm{~s}, 1 \mathrm{H}), 7.50-7.34$ $(\mathrm{m}, 8 \mathrm{H}), 5.22(\mathrm{~s}, 2 \mathrm{H}) ;{ }^{13} \mathrm{C} \mathrm{NMR}$ (DMSO, $\left.100 \mathrm{MHz}\right): \delta=194.18$, $171.55,166.92,161.82,156.96,150.50,134.87,134.34,132.79$, $131.79,130.00,128.89,123.26,119.99,118.86,115.56,113.91$, 112.97, 112.55, 46.92; MS (ES): $\mathrm{m} / z \quad 469.9 \quad[M-1]^{-}$; Anal. $\left(\mathrm{C}_{22} \mathrm{H}_{14} \mathrm{CINO}_{5} \mathrm{~S}_{2}\right) \mathrm{C}, \mathrm{H}, \mathrm{N}$.

(Z)-2-Hydroxy-4-(5-((3-methyl-4-oxo-2-thioxothiazolidin-5-ylidene)methyl)furan-2-yl)benzoic acid (16i): (yield: 38\%); Yellow solid; $\mathrm{mp}>300{ }^{\circ} \mathrm{C}$ (decomposition); ${ }^{1} \mathrm{H}$ NMR (DMSO, $400 \mathrm{MHz}$ ): $\delta=$ 7.86-7.84 (d, $1 \mathrm{H}, J=8 \mathrm{~Hz}), 7.55(\mathrm{~s}, 1 \mathrm{H}), 7.38-7.37(\mathrm{~d}, 1 \mathrm{H}, J=4 \mathrm{~Hz})$, 7.30-7.25 (m, 3H), $3.35(\mathrm{~s}, 3 \mathrm{H}) ;{ }^{13} \mathrm{C}$ NMR (DMSO, $\left.100 \mathrm{MHz}\right): \delta=$ $194.31,171.74,166.88,161.77,156.54,150.42,134.86,131.64$, $122.93,120.39,118.19,115.46,113.40,112.95,112.33,31.43$; MS (ES): $m / z 359.9[M-1]^{-}$; Anal. $\left(\mathrm{C}_{16} \mathrm{H}_{11} \mathrm{NO}_{5} \mathrm{~S}_{2}\right) \mathrm{C}, \mathrm{H}, \mathrm{N}$.

(Z)-2-Hydroxy-4-(5-((3-(4-methoxybenzyl)-4-oxo-2-thioxothiazolidin-5-ylidene)methyl)furan-2-yl)benzoic acid (16I): (yield: 37\%); Orange solid; $\mathrm{mp}=273^{\circ} \mathrm{C}$ (decomposition); ${ }^{1} \mathrm{H} N M R$ (DMSO, $400 \mathrm{MHz}): \delta=7.88-7.86(\mathrm{~d}, 1 \mathrm{H}, J=8.4 \mathrm{~Hz}), 7.63(\mathrm{~s}, 1 \mathrm{H}), 7.42-7.41$ $(\mathrm{d}, 1 \mathrm{H}, J=2.8 \mathrm{~Hz}), 7.33-7.27(\mathrm{~m}, 5 \mathrm{H}), 6.88-6.86(\mathrm{~d}, 2 \mathrm{H}, J=8 \mathrm{~Hz})$, $5.13(\mathrm{~s}, 2 \mathrm{H}), 3.70(\mathrm{~s}, 3 \mathrm{H}) ;{ }^{13} \mathrm{C}$ NMR (DMSO, $\left.100 \mathrm{MHz}\right): \delta=194.07$, $171.75,166.94,161.80,159.22,156.77,150.45,134.84,131.72$, $130.23,129.90,127.35,126.91,123.29,119.90,118.73,115.52$, 114.29, 113.55, 113.04, 112.42, 55.44, 46.98; MS (ES): $\mathrm{m} / \mathrm{z} 466.0$ $[M-1]^{-}$; Anal. $\left(\mathrm{C}_{23} \mathrm{H}_{17} \mathrm{NO}_{6} \mathrm{~S}_{2}\right) \mathrm{C}, \mathrm{H}, \mathrm{N}$. 
(Z)-4-(5-((3-(2-(1H-Indol-3-yl)ethyl)-4-oxo-2-thioxothiazolidin-5ylidene)methyl)furan-2-yl)-2-hydroxybenzoic acid $(16 \mathrm{~m})$ : (yield: $55 \%)$; Yellow-brown solid; $\mathrm{mp}=254^{\circ} \mathrm{C}$ (decomposition); ${ }^{1} \mathrm{H}$ NMR: $\left(\left(\mathrm{CD}_{3}\right)_{2} \mathrm{CO}, 400 \mathrm{MHz}\right) \delta=8.00-7.98(\mathrm{~d}, 1 \mathrm{H}, J=8.4 \mathrm{~Hz}), 7.76-7.74(\mathrm{~d}$, $1 \mathrm{H}, J=8 \mathrm{~Hz}), 7.64(\mathrm{~s}, 1 \mathrm{H}), 7.47-7.33(\mathrm{~m}, 5 \mathrm{H}), 7.22(\mathrm{~s}, 1 \mathrm{H}), 7.11-7.02$ $(\mathrm{m}, 2 \mathrm{H})$ 4.41-4.37 (m, 2H), 3.19-3.15 (m, 2H); ${ }^{13} \mathrm{C}$ NMR (DMSO, $100 \mathrm{MHz}): \delta=194.15,171.77,166.77,161.81,156.64,150.49$, $136.64,134.91,131.77,127.45,123.59,123.10,121.47,120.25$, 118.86, 118.53, 118.33, 115.53, 113.52, 113.09, 112.40, 111.90, 110.38, 45.23, 22.82; MS (ES): $\mathrm{m} / \mathrm{z} 489.0[\mathrm{M}-1]^{-}$; Anal. $\left(\mathrm{C}_{25} \mathrm{H}_{18} \mathrm{~N}_{2} \mathrm{O}_{5} \mathrm{~S}_{2}\right) \mathrm{C}, \mathrm{H}$, N.

(Z)-4-(5-((3-(3-Chlorobenzyl)-4-oxo-2-thioxothiazolidin-5-ylidene)methyl)furan-2-yl)-2-hydroxybenzoic acid (16n): (yield: $51 \%$ ); Yellow-brown solid; $\mathrm{mp}=289^{\circ} \mathrm{C}$ (decomposition); ${ }^{1} \mathrm{H}$ NMR: (DMSO, $400 \mathrm{MHz}) \delta=7.91-7.89(\mathrm{~d}, 1 \mathrm{H}, J=8.4 \mathrm{~Hz}), 7.69(\mathrm{~s}, 1 \mathrm{H}), 7.47-7.46$ $(\mathrm{d}, 1 \mathrm{H}, J=3.6 \mathrm{~Hz}), 7.39-7.35(\mathrm{~m}, 6 \mathrm{H}), 7.27-7.26(\mathrm{~d}, 1 \mathrm{H}, J=6.4 \mathrm{~Hz})$, $5.22(\mathrm{~s}, 2 \mathrm{H}) ;{ }^{13} \mathrm{C}$ NMR (DMSO, $100 \mathrm{MHz}$ ): $\delta=194.32,171.72,166.96$, $161.81,156.84,150.49,138.07,137.76,134.86,133.54,131.85$, 128.01, 126.53, 119.97, 119.03, 115.67, 115.49, 113.66, 113.23, 112.70, 46.92; MS (ES): $\mathrm{m} / \mathrm{z} 470.0[\mathrm{M}-1]^{-}$; Anal. $\left(\mathrm{C}_{22} \mathrm{H}_{14} \mathrm{CINO}_{5} \mathrm{~S}_{2}\right) \mathrm{C}$, $\mathrm{H}, \mathrm{N}$.

\section{Docking studies}

Docking studies of all the synthesized compounds were performed within the DNA binding domain of IN using the software package Gold 4.1. ${ }^{[35-37]}$ GoldScore was chosen as the fitness function. The genetic algorithm parameter settings of Gold were employed using the Search efficiency set at $100 \%$. Thirty runs were carried out for each ligand. Results differing by $<1.5 \AA$ in ligand all-atom root mean square deviation (RMSD) were clustered together. For each inhibitor, the first-ranked solution as well as the lowestenergy conformation of the most populated cluster were analyzed.

Three structures of the protein, characterized by different loop conformations, were used for docking calculations, as previously described. ${ }^{[14]}$ The $\mathrm{Mg}^{2+}$-bound water molecules were kept during the docking calculations by using the option toggle (water molecules can be displaced during the docking at the cost of a penalty). Structures of inhibitors were built using Maestro 3D-sketcher, minimized with the OPLS_2005 force field, using the Polak-Ribiere conjugated gradient method $\left(0.001 \mathrm{~kJ}^{-1} \mathrm{~mol}^{-1}\right.$ convergence), and finally, docked in the protein. ${ }^{[38,39]}$ Among the three studied conformations of the protein, in the structure PDB ID: $1 \mathrm{BL} 3,{ }^{[40]}$ all the studied inhibitors showed a high score value. Therefore, structure 1BL3 was chosen for the analysis of the ligand-protein complexes. Finally, post-docking analysis was performed, and Figures 3, 4, and 5 were created using the program PyMOL (version 1.2). ${ }^{[41]}$

\section{Biology}

Integrase assays: The enzymatic integration reactions were carried out with minor modifications as described previously. ${ }^{[32]}$ To determine the susceptibility of the HIV-1 IN enzyme to different compounds, we used an enzyme-linked immunosorbent assay (ELISA). ${ }^{[42]}$ The overall integration assay uses an oligonucleotide substrate for which one oligonucleotide (5'-ACT GCT AGA GAT TाT CCA CAC TGA CTA AAA GGG TC- $3^{\prime}$ ) is labeled with biotin at the $3^{\prime}$ end and the other oligonucleotide ( $5^{\prime}$-GAC CCT TTT AGT CAG TGT GGA AAA TCT (TA GCA GT-3') is labeled with digoxigenin at the $5^{\prime}$ end. The IN enzyme was diluted in $750 \mathrm{~mm} \mathrm{NaCl}, 10 \mathrm{~mm}$ Tris (pH 7.6), $10 \%$ glycerol, and $1 \mathrm{~mm} \beta$-mercaptoethanol. To perform the reaction, $4 \mu \mathrm{L}$ diluted IN (corresponding to a concentration of
$1.6 \mu \mathrm{M})$ and $4 \mu \mathrm{L}$ annealed oligonucleotides (7 nм) were added in a final reaction volume of $40 \mu \mathrm{L}$ containing $10 \mathrm{mM} \mathrm{MgCl}, 5 \mathrm{mM}$ dithiothreitol, $20 \mathrm{~mm}$ HEPES ( $\mathrm{pH} 7.5$ ), $5 \%$ poly(ethylene glycol), and $15 \%$ DMSO. The final concentration of IN in this assay was $160 \mathrm{~nm}$. The reaction was carried out for $1 \mathrm{~h}$ at $37^{\circ} \mathrm{C}$. Reaction products were denatured with $30 \mathrm{~mm} \mathrm{NaOH}$ and detected by ELISA on avidin-coated plates.

Anti-HIV activity in lymphoid cells: The biological activity of the compounds was tested in the lymphoid MT-4 cell line (received from the NIH AIDS Reagent Program) against the wild-type HIV-1 NL4-3 strain. In brief, MT-4 cells were infected with the appropriate HIV-1 strain (or mock-infected to determine cytotoxicity) in the presence of various drug concentrations. At day five post-infection, a tetrazolium-based colorimetric method (MTT method) was used to evaluate the number of viable cells. ${ }^{[33,34]}$

\section{Abbreviations}

$\mathrm{DME}, 1,2$-dimethoxyethane; DMF, N,N-dimethylformamide; DMSO, dimethyl sulfoxide; $P E$, petroleum ether; $S D$, standard deviation; TBAF, tetra- $n$-butylammonium fluoride; THF, tetrahydrofuran; TIPSCl, triisopropylsilyl chloride; TMSCl, trimethylsilyl chloride.

\section{Acknowledgements}

This work was supported by the European Union collaborative projects: "THINC" (grant no. HEALTH-2007-2.3.2-1) and "CHAARM" (grant no. HEALTH-F3-2009-242135). It was also supported by the Italian Ministero dell'Istruzione, dell'Università e della Ricerca, Prin 2008 research project (grant no. 2008CE75SA_004). We thank Barbara van Remoortel and Martine Michiels for excellent technical assistance. F.C. is supported by a grant from the Industrial Research Fund (IOF) from the Katholieke Universiteit Leuven (Flanders, Belgium).

Keywords: antiviral agents · HIV · inhibitors · integrase

[1] D. C. Meadows, J. Gervay-Hague, ChemMedChem 2006, 1, 16-29.

[2] E. De Clercq, J. Med. Chem. 2005, 48, 1297-1313.

[3] P. Yin, D. Das, H. Mitsuya, Cell. Mol. Life Sci. 2006, 63, 1706-1724.

[4] T. Imamichi, Curr. Pharm. Des. 2004, 10, 4039-4053.

[5] R. Dayam, R. Gundla, L. Q. Al-Mawsawi, N. Neamati, Med. Res. Rev. 2008 28, $118-154$.

[6] T. H. Evering, M. Markowitz, Drugs Today 2007, 43, 865-877.

[7] V. Summa, A. Petrocchi, F. Bonelli, B. Crescenzi, M. Donghi, M. Ferrara, F. Fiore, C. Gardelli, O. G. Paz, D. J. Hazuda, P. Jones, O. Kinzel, R. Laufer, E. Monteagudo, E. Muraglia, E. Nizi, F. Orvieto, P. Pace, G. Pescatore, R. Scarpelli, K. Stillmock, M. V. Witmer, M. Rowley, J. Med. Chem. 2008, 51, 5843-5855.

[8] D. Esposito, R. Craigie, Adv. Virus Res. 1999, 52, 319-333.

[9] Y. Goldgur, R. Craigie, G. H. Cohen, T. Fujiwara, T. Yoshinaga, T. Fujishita, H. Sugimoto, T. Endo, H. Murai, D. R. Davies, Proc. Natl. Acad. Sci. USA 1999, 96, 13040-13043.

[10] F. Christ, W. Thys, J. De Rijck, R. Gijsbers, A. Albanese, D. Arosio, S. Emiliani, J. C. Rain, R. Benarous, A. Cereseto, Z. Debyser, Curr. Biol. 2008, 18, $1192-1202$.

[11] D. J. Hazuda, P. Felock, M. Witmer, A. Wolfe, K. Stillmock, J. A. Grobler, A. Espeseth, L. Gabryelski, W. Schleif, C. Blau, M. D. Miller, Science 2000, $287,646-650$.

[12] Y. Pommier, A. A. Johnson, C. Marchand, Nat. Rev. Drug Discovery 2005 4, $236-248$.

[13] S. Hare, S. S. Gupta, E. Valkov, A. Engelman, P. Cherepanov, Nature 2010, $464,232-237$. 
[14] C. Mugnaini, S. Rajamaki, C. Tintori, F. Corelli, S. Massa, M. Witvrouw, Z. Debyser, V. Veljkovic, M. Botta, Bioorg. Med. Chem. Lett. 2007, 17, $5370-$ 5373.

[15] C. Tintori, F. Manetti, N. Veljkovic, V. Perovic, J. Vercammen, S. Hayes, S. Massa, M. Witvrouw, Z. Debyser, V. Veljkovic, M. Botta, J. Chem. Inf. Model. 2007, 47, 1536-1544.

[16] C. Tintori, V. Corradi, M. Magnani, F. Manetti, M. Botta, J. Chem. Inf. Model. 2008, 48, 2166-2179.

[17] S. Rajamaki, A. Innitzer, C. Falciani, C. Tintori, F. Christ, M. Witvrouw, Z. Debyser, S. Massa, M. Botta, Bioorg. Med. Chem. Lett. 2009, 19, 36153618

[18] F. Dyda, A. B. Hickman, T. M. Jenkins, A. Engelman, R. Craigie, D. R. Davies, Science 1994, 266, $1981-1986$.

[19] D. Esposito, R. Craigie, EMBO J. 1998, 17, 5832-5843.

[20] A. A. Johnson, C. Marchand, S. S. Patil, R. Costi, S. R. Di, T. R., Jr. Burke, Y. Pommier, Mol. Pharmacol. 2007, 71, 893-901.

[21] L. Franchi, M. Rinaldi, G. Vignaroli, A. Innitzer, M. Radi, M. Botta, Synthesis 2010, 3927-3933.

[22] M. Anderluh, M. Jukic, R. Petric, Tetrahedron 2009, 65, 344-350.

[23] K. Bourahla, A. Derdour, M. Rahmouni, F. Carreaux, J. P. Bazureau, Tetrahedron Lett. 2007, 48, 5785-5789.

[24] B. Hu, M. Malamas, J. Ellingboe, E. Largis, S. Han, R. Mulvey, J. Tillett Bioorg. Med. Chem. Lett. 2001, 11, 981 -984.

[25] M. Pulici, F. Quartieri, Tetrahedron Lett. 2005, 46, 2387-2391.

[26] M. Radi, L. Botta, G. Casaluce, M. Bernardini, M. Botta, J. Comb. Chem. 2010, 12, 200-205.

[27] P. Fresneau, M. Cussac, J. M. Morand, B. Szymonski, D. Tranqui, G. Leclerc, J. Med. Chem. 1998, 41, 4706-4715.

[28] P. Fresneau, J. M. Morand, F. Thomasson, M. Cussac, Spectrochim. Acta, Part A 1999, 55, 2893-2898.

[29] P. C. Unangst, D. T. Connor, W. A. Cetenko, R. J. Sorenson, C. R. Kostlan, J. C. Sircar, C. D. Wright, D. J. Schrier, R. D. Dyer, J. Med. Chem. 1994, 37 $322-328$.
[30] P. Vicini, A. Geronikaki, K. Anastasia, M. Incerti, F. Zani, Bioorg. Med. Chem. 2006, 14, 3859-3864.

[31] M. Dubois, F. Bailly, G. Mbemba, J. F. Mouscadet, Z. Debyser, M. Witvrouw, P. Cotelle, J. Med. Chem. 2008, 51, 2575-2579.

[32] Z. Debyser, P. Cherepanov, W. Pluymers, E. De Clercq, Methods Mol. Biol. 2001, 160, 139- 155 .

[33] G. Moncunill, M. Armand-Ugón, E. Pauls, B. Clotet, J. A. Esté, AIDS 2008, $22,23-31$.

[34] G. Moncunill, M. Armand-Ugón, I. Clotet-Codina, E. Pauls, E. Ballana, A. Llano, B. Romagnoli, J. W. Vrijbloed, F. O. Gombert, B. Clotet, S. De MarCo, J. A. Esté, Mol. Pharmacol. 2008, 73, 1264.

[35] G. Jones, P. Willett, R. C. Glen, J. Mol. Biol. 1995, 245, 43-53.

[36] G. Jones, P. Willett, R. C. Glen, A. R. Leach, R. Taylor, J. Mol. Biol. 1997, 267, 727-748.

[37] M. L. Verdonk, J. C. Cole, M. J. Hartshorn, C. W. Murray, R. D. Taylor, Proteins Struct. Funct. Bioinf. 2003, 52, 609-623.

[38] Maestro, ver. 8.5, Schrödinger, New York, NY (USA), 2008.

[39] W. L. Jorgensen, D. S. Maxwell, J. Tirado-Rives, J. Am. Chem. Soc. 1996, $118,11225-11236$.

[40] S. Maignan, J.-P. Guilloteau, Q. Zhou-Liu, C. Clément-Mella, V. Mikol, J. Mol. Biol. 1998, 282, 359-368.

[41] W. L. DeLano, The PyMOL Molecular Graphics System, DeLano Scientific LLC, San Carlos, CA (USA): http://www.pymol.org.

[42] Y. Hwang, D. Rhodes, F. Bushman, Nucleic Acids Res. 2000, 28, $4884-$ 4892.

Received: November 25, 2010

Revised: December 22, 2010

Published online on January 18, 2011 